\title{
ENPP1, an Old Enzyme with New Functions, and Small Molecule Inhibitors-A STING in the Tale of ENPP1
}

\author{
Kenneth I. Onyedibe ${ }^{1,2} \oplus$, Modi Wang ${ }^{1}$ and Herman O. Sintim ${ }^{1,2,3, *}$ \\ 1 Chemistry Department, Institute for Drug Discovery, Purdue University, West Lafayette, IN 47907, USA; \\ konyedib@purdue.edu (K.I.O.); wang3684@purdue.edu (M.W.) \\ 2 Purdue Institute for Inflammation, Immunology, and Infectious Diseases, West Lafayette, IN 47907, USA \\ 3 Purdue University Center for Cancer Research, West Lafayette, IN 47907, USA \\ * Correspondence: hsintim@purdue.edu; Tel.: +1-(765)-496-6078; Fax: +1-(765)-494-0239
}

Academic Editors: Liliya Yatsunyk and David Monchaud

Received: 24 September 2019; Accepted: 13 November 2019; Published: 19 November 2019

check for updates

\begin{abstract}
Ectonucleotide pyrophosphatase/phosphodiesterase I (ENPP1) was identified several decades ago as a type II transmembrane glycoprotein with nucleotide pyrophosphatase and phosphodiesterase enzymatic activities, critical for purinergic signaling. Recently, ENPP1 has emerged as a critical phosphodiesterase that degrades the stimulator of interferon genes (STING) ligand, cyclic GMP-AMP (cGAMP). cGAMP or analogs thereof have emerged as potent immunostimulatory agents, which have potential applications in immunotherapy. This emerging role of ENPP1 has placed this "old" enzyme at the frontier of immunotherapy. This review highlights the roles played by ENPP1, the mechanism of cGAMP hydrolysis by ENPP1, and small molecule inhibitors of ENPP1 with potential applications in diverse disease states, including cancer.
\end{abstract}

Keywords: cyclic dinucleotide; cGAMP; ENPP1; cancer

\section{Introduction}

Ectonucleotide pyrophosphatase/phosphodiesterase 1 (ENPP1), also called PC-1, is a type II transmembrane glycoprotein with nucleotide pyrophosphatase and phosphodiesterase enzymatic activities [1]. In 1970, Takahashi et al. showed that PC-1 (or ENPP1) was a $115 \mathrm{kDa}$ and $230 \mathrm{kDa}$ protein under reducing and non-reducing conditions, respectively [2]. ENPP1 is expressed in many tissues [3] and is critical for purinergic signaling, which plays an important role in the regulation of cardiovascular, neurological, immunological, musculoskeletal, hormonal, and hematological functions in mammals $[4,5]$.

Specifically, purinergic signaling is involved in platelet aggregation, muscle contraction, cell proliferation, migration, differentiation, and apoptosis, as well as in regulating hypoxia and ischemia in tissues [4]. Purinergic receptors are divided into two major families, P1 and P2 receptors [6]. P1 receptors are mediated by adenosine, while $\mathrm{P} 2$ receptors (P2X and P2Y) are mediated by nucleotides, such as ATP and uridine-5'-triphosphate (UTP) [6]. The extracellular levels of these nucleotides are tightly controlled by their hydrolysis, which is mediated by membrane-bound ENPP1 [7]. ENPP1 catalyzes the hydrolysis of ATP or GTP to AMP or GMP, while generating inorganic pyrophosphates (PPi) [8]. Inorganic pyrophosphates inhibit bone and cartilage mineralization [7,9]. Therefore, the generation of PPi by ENPP1 inadvertently makes ENPP1 a central regulator of bone and cartilage development in mammals [7]. Thus, many inherited mineralization, calcium handling or calcification-related disorders have been linked to loss-of-function mutations in ENPP1, including autosomal recessive hypophosphatemic rickets type 2 (ARHR2), ossification of the posterior longitudinal ligament of 
the spine, generalized arterial calcification of infancy (GACI), arterial calcification due to CD73 deficiency (ACDC), and pseudoxanthoma elasticum (PXE), also referred to as Gronblad-Strandberg Syndrome (GSS) in some reports [10-13]. Some classical manifestations of these diseases, such as vascular involvement, are common in ACDC, PXE, and GACI [13-15]. These conditions are all ectopic mineralization disorders that occur in the presence of ENPP1 mutations, and have led to the hypothesis that PXE and GACI are actually different manifestations of the same clinical spectrum $[13,15]$. Recently, Staretz-Chacham et al. reported a fatal multisystemic phenotype of GACI that mimics severe congenital infections and was caused by a novel homozygous ENPP1 mutation [16]. Inactivating mutations of ENPP1, which cause ARHR2, have also been shown to increase the transcription of fibroblast growth factor (FGF) 23 in osteoblasts and osteocytes by a mechanism that has not been fully characterized $[10,17,18]$. Fibroblast growth factor 23 released from osteoblasts and osteocytes regulates vitamin D metabolism and phosphate homeostasis [17,19]. Additionally, Cole diseases, as well as recently characterized forms of dyschromatoses, have been linked to mutations in ENPP1 [11,20]. Interestingly, Chourabi et al. reported that dyschromatoses patients with ENPP1 mutations also consistently had alterations in their melanocyte development and pigmentation signaling pathways [20]. In addition, insulin resistance, a fundamental starting point for most metabolic diseases, has been linked with ENPP1 mutations in several studies [7,21-23]. Huesa et al. observed that ENPP1 knockout mice resisted the expected progression to obesity and insulin resistance despite prolonged high-fat diets [24].

Recently, ENPP1 has been found to play an important role in the immunological responses to various stimuli through the cyclic GMP-AMP synthase (cGAS)-stimulator of interferon genes (STING) pathway [25]. Damage associated molecular patterns (DAMPs) as well as pathogen associated molecular patterns (PAMPs) activate the immune system via STING [26]. cGAS senses cytosolic DNA and catalyzes the conversion of GTP and ATP to cyclic GMP-AMP (cGAMP) $[27,28]$. Subsequently, $2^{\prime} 3^{\prime}$-cGAMP activates STING to initiate an inflammatory response via the TANK-binding kinase 1 (TBK1)-Interferon Regulatory Factor (IRF) 3 pathway to produce type 1 interferons (IFNs) and other cytokines [27]. A link between the cGAS-STING pathway and ENPP1 has emerged whereby the hydrolysis of cGAMP by ENPP1 attenuates cGAS-STING signaling [25,29-32] (Figure 1a). Li et al. reported that the half-life of cGAMP is largely dependent on ENPP1 by demonstrating a much longer cGAMP half-life in ENPP1 knockout mice [32]. Bisphosphothionate analogs of 2'3'-cGAMP, which are resistant to ENPP1 hydrolysis, were shown to activate STING more than 10-fold, compared to 2'3'-cGAMP [32], thus, implying that delayed or reduced cGAMP hydrolysis by inhibition of ENPP1 would significantly increase the activation of STING. Wang et al. recently showed that ENPP1 inhibition attenuates pseudo-rabies infections through alteration of cGAMP homeostasis [30]. Pseudo-rabies is a viral infection, and it has recently emerged that some other viruses, such as pox virus, possess cytosolic immune nucleases (poxins), which degrade 2' $3^{\prime}$-cGAMP and make it unable to activate STING [33]. These poxins are believed to be viral self-protective enzymes that prevent $2^{\prime} 3^{\prime}$-cGAMP from activating STING [33]. Likewise, Dey et al. reported that Mycobacterium tuberculosis (Mtb) could inhibit STING activation and evade host immunity via the concerted action of cyclic dinucleotide phosphodiesterase (CdnP) and ENPP1 (Figure 1b) [31]. Cyclic-di-AMP and cyclic-di-GMP (Figure 2) from invading pathogens also activate the cGAS-STING pathway in the same manner as $2^{\prime} 3^{\prime}$-cGAMP [27]. 
(a)

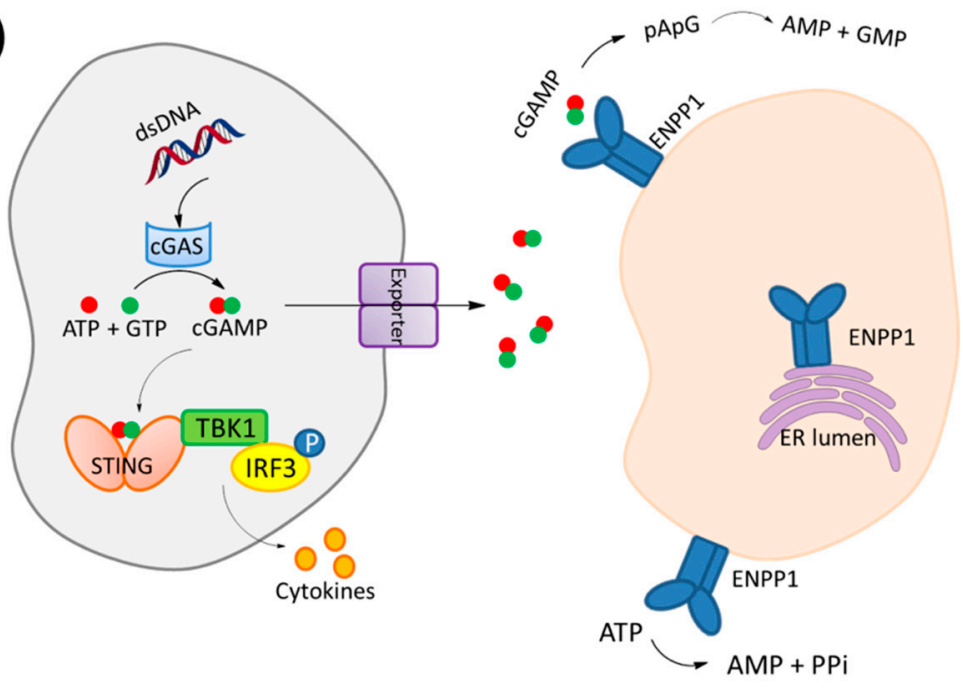

(b)

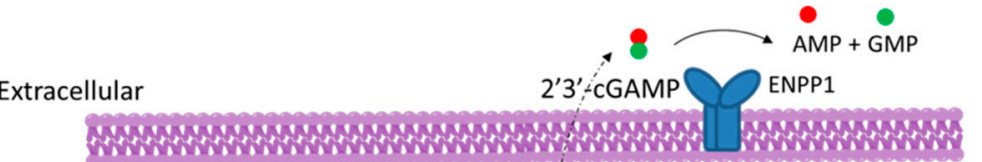

Intracellular

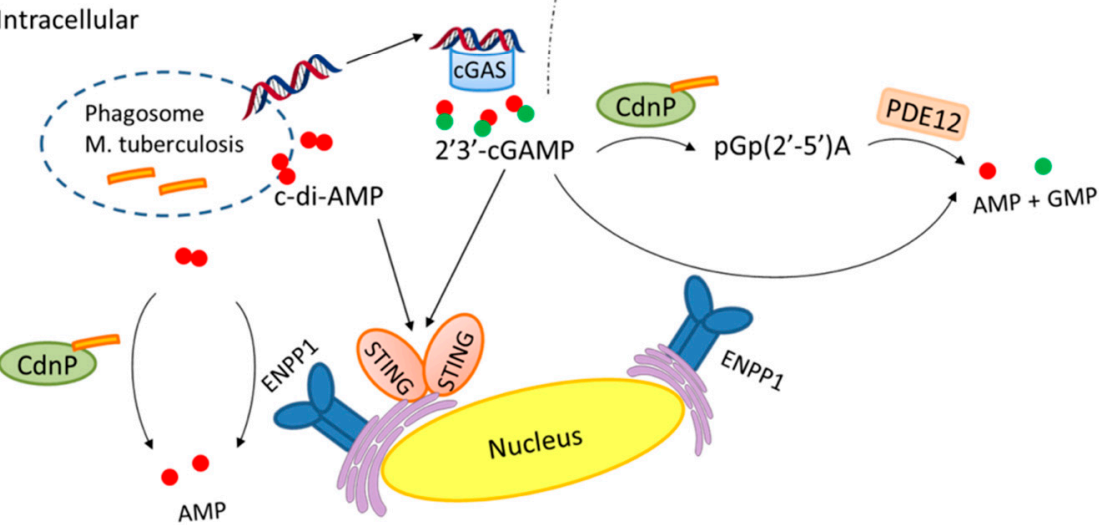

Figure 1. (a) Scheme of Ectonucleotide pyrophosphatase/phosphodiesterase 1 (ENPP1) function in the cyclic GMP-AMP synthase (cGAS)-stimulator of interferon genes (STING) pathway. (b) Scheme for cyclic dinucleotide signaling and inhibition of cGAS-STING pathway by M. tuberculosis' cyclic dinucleotide phosphodiesterase (CdnP). Figure $1 \mathrm{~b}$ adapted from Reference [24] with permission from Springer Nature Limited, Copyright 2016.

In addition to being a target for bone [7,34], cardiovascular [35], and metabolic diseases [23], ENPP1 has now emerged as a therapeutic target for cancers, as discussed below [36]. ENPP1 plays a regulatory function in immune cells such as neutrophils, macrophages, dendritic cells, natural killer cells, and B lymphocytes [37,38]. ENPP1 expression is heightened in M2 macrophages in the presence of cancer and promotes tumor growth and spread [30,39]. The location of the gene for ENPP1 is the 6q22-q23 position, which is a region that has been found to be amplified in many tumors, including breast and neural brain cancers [40,41]. Clearly, ENPP1 inhibitors would play an important role in cancer immunotherapy. Although other excellent reviews on ENPP1 inhibitors have been published, these were published before the new role of ENPP1 in modulating the immunomodulatory ligand, cGAMP, was discovered or fully elucidated [42]. Here, we present the current state of knowledge of ENPP1 and inhibitors, which could be used to modulate ENPP1 function. 

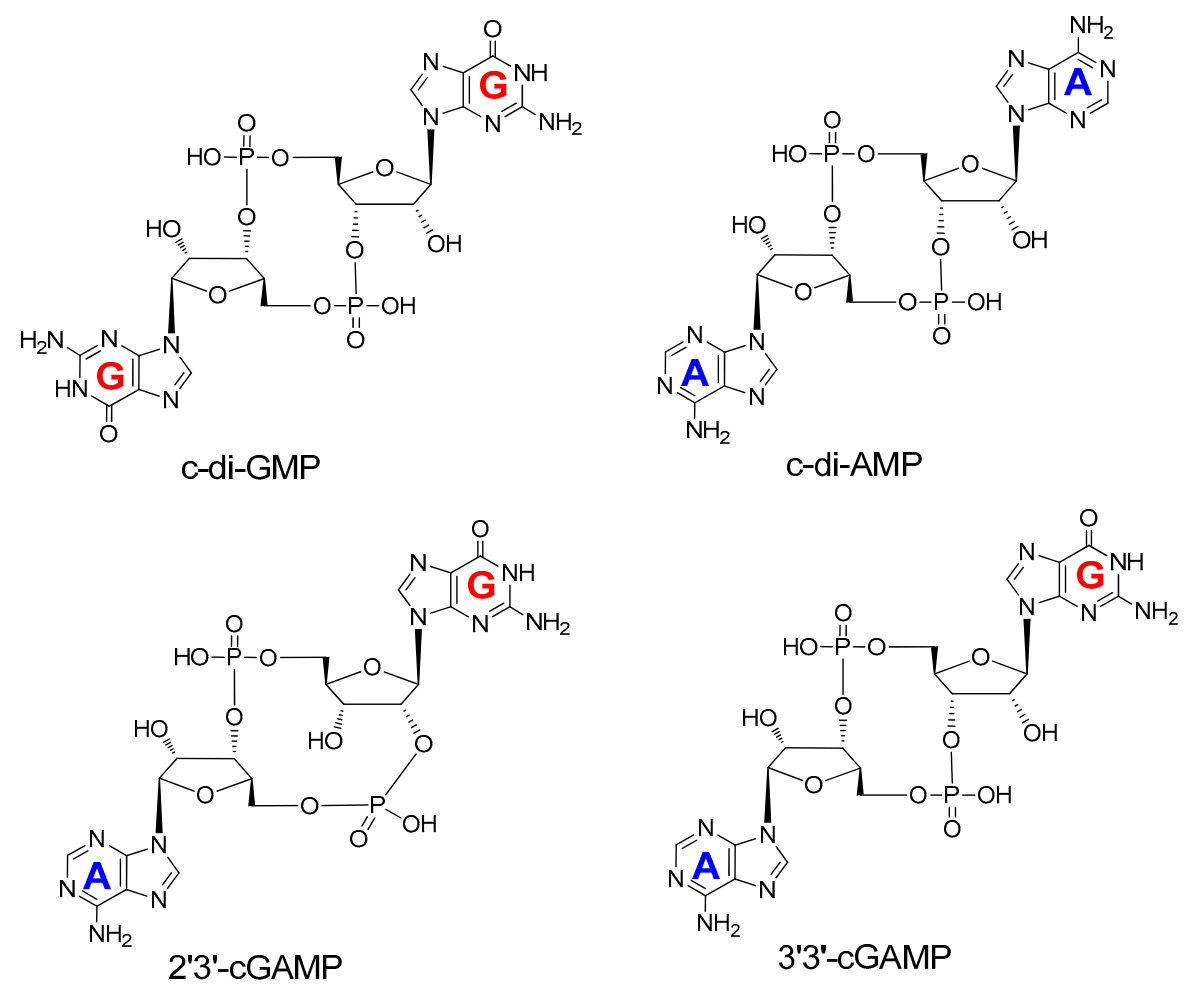

Figure 2. Structures of different cyclic dinucleotides: c-di-GMP, c-di-AMP, 2' $3^{\prime}$-cGAMP, and $3^{\prime} 3^{\prime}$-cGAMP.

\section{Mechanism of Hydrolysis of ATP and 2' $3^{\prime}$-cGAMP by ENPP1}

ENPP1 is located on plasma membranes and ER lumen [43]. One of the main substrates of ENPP1 is ATP, a pro-inflammatory signaling molecule. The level of ATP is relatively high in the tumor microenvironment due to the presence of damaged or dying cells [44]. Hydrolysis of ATP by ENPP1 would produce AMP and PPi extracellularly (Figure 3a) to prevent bone mineralization $[45,46]$. AMP is then dephosphorylated to adenosine by the ecto-5'-nucleotidase (CD73) in the canonical adenosinergic pathway [47].

Kato et al. reported the crystal structures of the ENPP1 extracellular domain bound to four nucleotide monophosphates (MP), (adenosine (AMP), thymidine (TMP), guanosine (GMP), and cytidine (CMP)) at resolutions of 2.7-3.2 $\AA$, in 2012 [21]. The ENPP1 structure has two N-terminal somatomedin B (SMB)-like domains (SMB1 and SMB2), two linker regions (L1 and L2), a catalytic domain, and a nuclease-like domain (Figure 4a). There are three glycosylation sites for ENPP1, which reinforce the domain interaction [21]. It was believed that the SMB-like domains functioned as a transmembrane anchor and were not involved in the enzymatic activity of ENPP1. On the other hand, ENPP1 is a $\mathrm{Ca}^{2+}$ - and $\mathrm{Zn}^{2+}$-dependent enzyme, and enzymatic activity is strongly correlated to the concentration of calcium and zinc ions [21]. The nuclease-like domain of ENPP1 contains a calcium ion-binding EF hand motif, which is found in a large family of calcium-binding proteins. The calcium ion is chelated by Asp780, Asp782, Asp784, and Asp788, and the carbonyl group of Arg786 to form an EF hand-like motif (Figure 4b). The catalytic domain chelates two zinc ions in the active site, a location which plays an important role in the function of ENPP1 [21]. The phosphate group of ATP binds in between the two zinc ions to trigger the bond cleavage process and produce AMP and PPi. The nitrogen- 6 atom of AMP interacts with Trp304 and Asp308 by a $\mathrm{H}_{2} \mathrm{O}$-mediated hydrogen bond network. However, no hydrogen-bonding network is formed for TMP, GMP, and CMP, thereby resulting in the selectivity of ENPP1 for ATP. Hence, ATP is the most efficient and well-investigated substrate for ENPP1. There are other reported natural substrates of ENPP1 including $\mathrm{UTP}$, diadenosine tetraphosphate $\left(\mathrm{AP}_{4} \mathrm{~A}\right)$, cyclic adenosine monophosphate (cAMP), and $2^{\prime} 3^{\prime}$-cGAMP, 
but not 3'3'-cGAMP (Figure 2) [48]. It is already known that cyclic nucleotides, such as cAMP and cGMP, are exported by multidrug resistance proteins (MRPs) [49-51]. Recently, it was also shown that some cyclic dinucleotides (such as cyclic-di-AMP) were exported by MRPs [52]. Cyclic nucleotides are degraded by phosphodiesterases (PDEs) 1 to 11 [53]. However, these PDEs do not degrade cyclic dinucleotides, such as $2^{\prime} 3^{\prime}$-cGAMP. Viral poxins and ENPP1 are now the known hydrolytic enzymes of $2^{\prime} 3^{\prime}$-cGAMP [32,33]. ENPP1 hydrolyzes $2^{\prime} 3^{\prime}$-cGAMP with a kinetic rate constant that is similar to the hydrolysis of ATP (Figure 3b) [32].

(a)

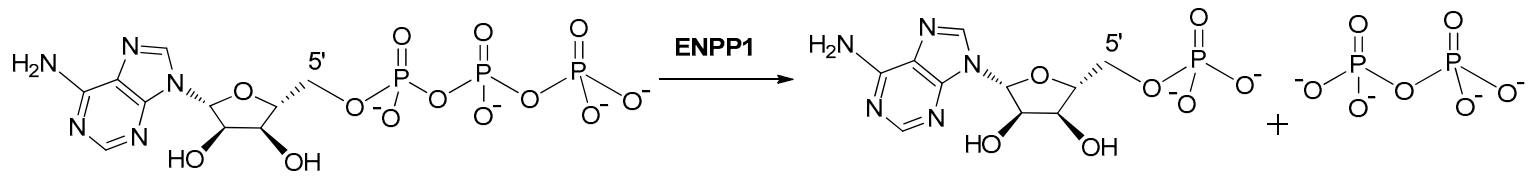

ATP

AMP

$\mathbf{P P}_{\mathbf{i}}$

(b)

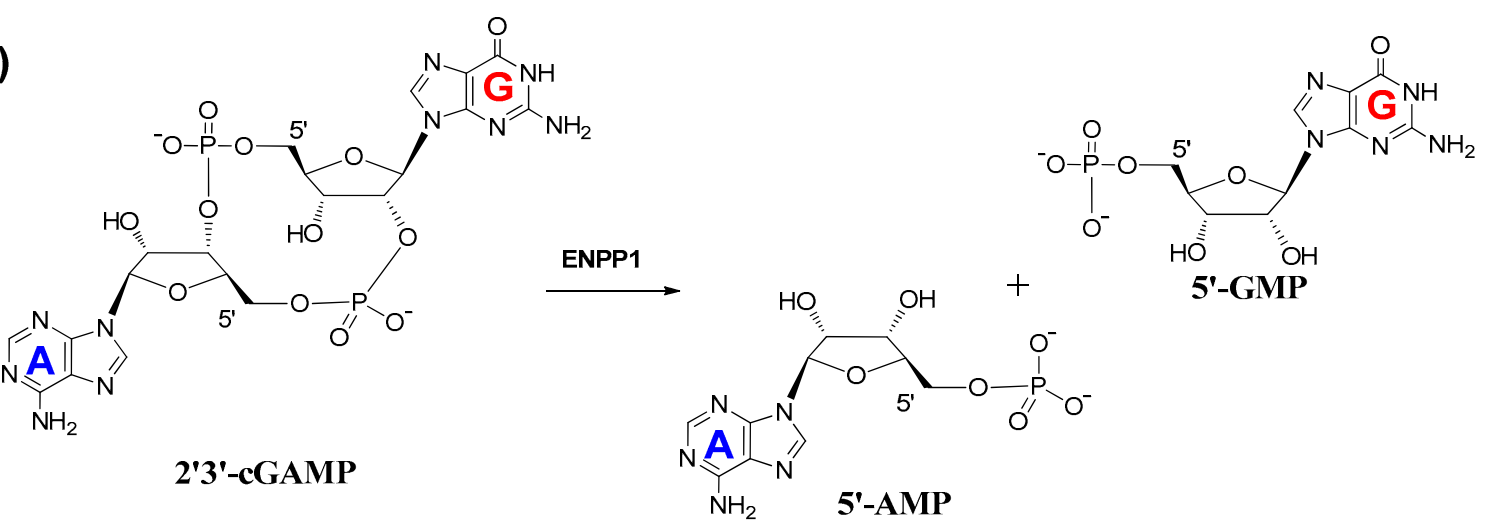

Figure 3. Hydrolysis of substrates (a) ATP and (b) 2'3'-cGAMP by ENPP1.

(a)

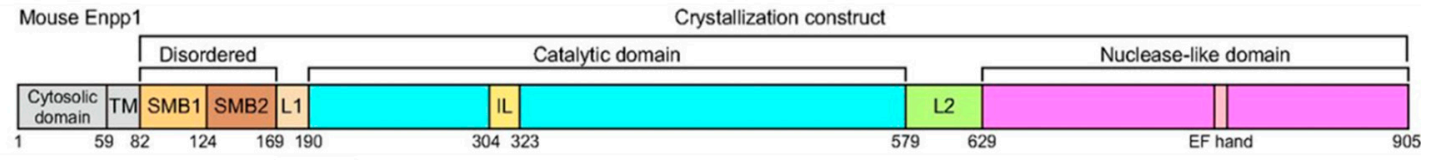

(b)

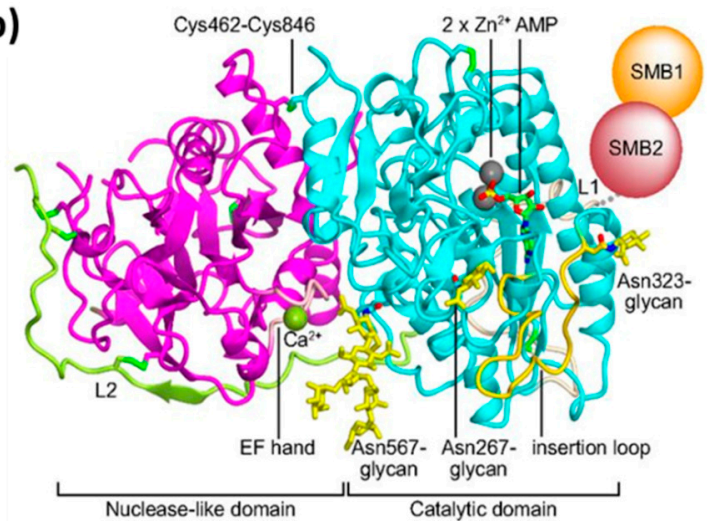

Figure 4. (a) Domain organization of mouse ENPP1. (b) Crystal structure of the extracellular domain of ENPP1 in complex with AMP. Catalytic domain, cyan; nuclease-like domain, magenta; L1, wheat; L2, yellow-green; EF hand-like motif, pink; insertion loop, gold. AMP and N-glycans are shown as green and yellow sticks, respectively. The bound zinc and calcium ions are shown as gray and yellow-green spheres, respectively. Disulfide linkages are shown as sticks. The two somatomedin B (SMB)-like domains are shown by circles, as they are disordered in the crystal structure [21]. Reproduced from Reference [21] with permission from National Academy of Sciences, Copyright 2012. 
To understand the mechanism of 2'3'-cGAMP hydrolysis by ENPP1, Kato et al. investigated the crystal structure of ENPP1 in complex with 2'3'-cGAMP (Figure 5) [25]. ENPP1 utilizes two $\mathrm{Zn}^{2+}$ ions, coordinated by Asp358/His362/His517 and Asp200/Asp405/His406, to interact with the phosphate oxygen. The enzyme hydrolyzes the $2^{\prime}-5^{\prime}$ phosphodiester bond of $2^{\prime} 3^{\prime}$-cGAMP first to form phosphoadenylyl guanosine (pApG) and then a second hydrolysis produces $5^{\prime}$-AMP and 5'-GMP [25]. Recently, Eaglesham et al. described cGAMP hydrolysis by viral and metazoan poxins [33]. However, the mechanism for cGAMP hydrolysis by poxin is different from that of ENPP1. Firstly, cGAMP binds to ENPP1 as the anion and one of the phosphates coordinates to two zinc ions ligated by histidine and aspartate residues, as shown in Figure 5c, whereas, cGAMP binds to poxin as the acid with no active site metal (Figure 6a) [33]. Additionally, for ENPP1, an O $\gamma$ atom of a threonine residue (Thr 238) is the nucleophile for hydrolysis, whereas in the poxin mechanism, the nucleophile for phosphate cleavage is the $2^{\prime} \mathrm{OH}$ of the cGAMP. In addition, for the poxin hydrolysis mechanism, histidine (H17) and tyrosine (Y138) act as general acids, whereas lysine (K142) acts as a general base to deprotonate 2'OH on cGAMP. The first stage of the poxin hydrolysis leads to a $2^{\prime}-3^{\prime}$-cyclic phosphate, which is then hydrolyzed by an active site hydroxyl ion $\left(\mathrm{OH}^{-}\right)$, as seen in Figure $6 \mathrm{~b}$. Another difference between the poxin and ENPP1 mechanisms of hydrolysis of cGAMP is that ENPP1 cleaves the $2^{\prime}-5^{\prime}$ phosphodiester bond first, followed by cleavage of the $3^{\prime}-5^{\prime}$ bonds, whereas poxins only cleave the $3^{\prime}-5^{\prime}$ phosphodiester bond [25,33]. Notwithstanding these differences, both types of hydrolysis ensure that the hydrolyzed $2^{\prime} 3^{\prime}$-cGAMP is not able to activate the STING pathway.

(a)

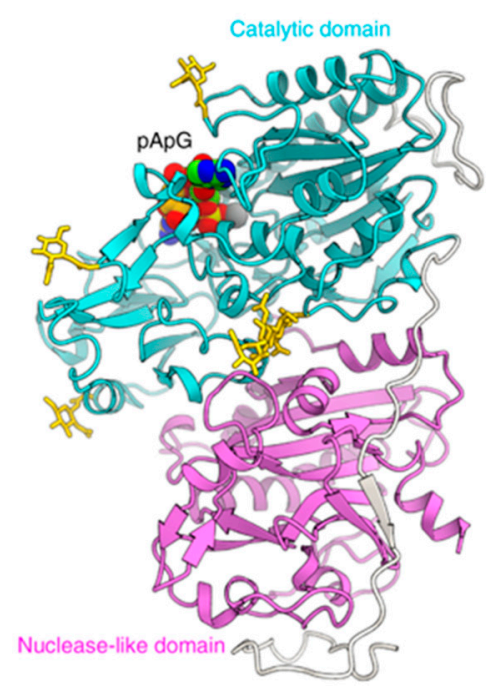

(b)

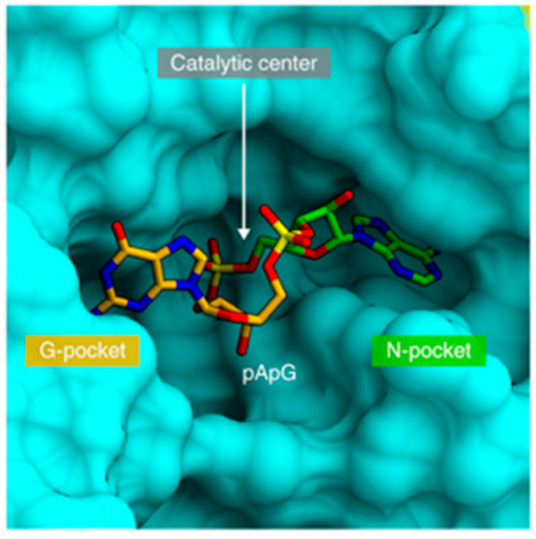

(c)

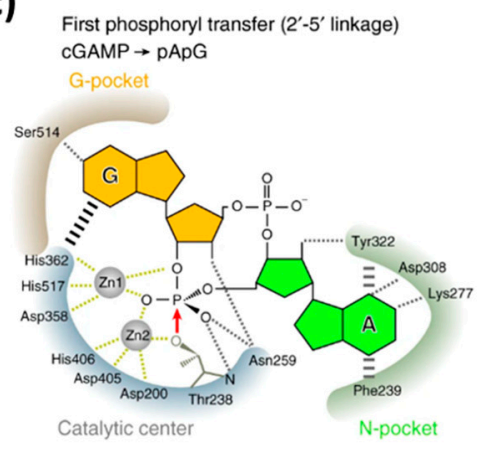

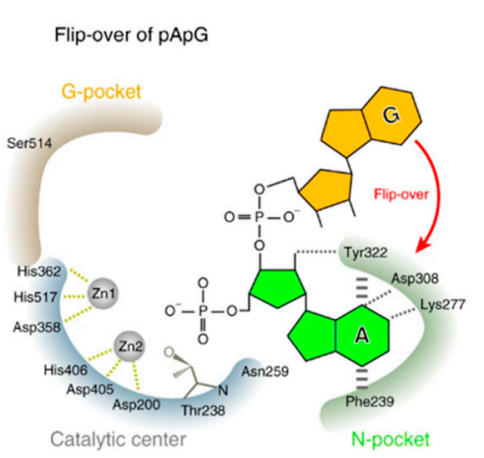

Second phosphoryl transfer $\left(3^{\prime}-5^{\prime}\right.$ linkage $)$ $\mathrm{pApG} \rightarrow 5^{\prime}-\mathrm{AMP}+5^{\prime}-\mathrm{GMP}$

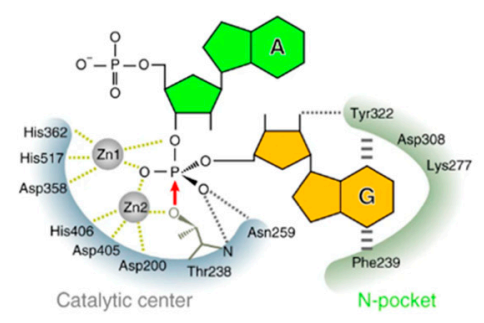

Figure 5. (a) Overall structure of ENPP1 in complex with phosphoadenylyl guanosine (pApG). The $\mathrm{N}$-linked sugars are shown as yellow sticks. (b) Binding of pApG to the ENPP1 active site. (c) Proposed mechanism of the ENPP1-catalyzed 2'3'-cGAMP degradation [25]. Reproduced from Reference [25] with permission from Springer Nature Limited, Copyright 2018. 
(a)

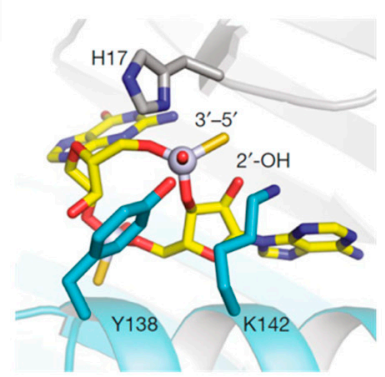

(b)

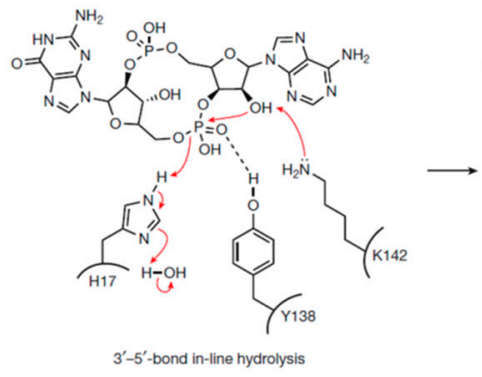

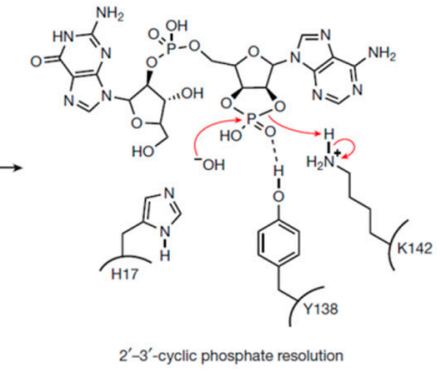

Figure 6. (a) Crystal structure of Vaccinia virus poxin-2' $13^{\prime}$-cGAMP complex highlighting residues involved in 3'-5'-bond hydrolysis. (b) Mechanism of poxin metal-independent hydrolysis [33]. Reproduced from Reference [33] with permission from Springer Nature Limited, Copyright 2019.

\section{STING and ENPP1 in Cancer}

Several studies have shown that STING pathway activation could stimulate anti-inflammatory $T$ cell responses via the induction of indoleamine 2,3 dioxygenase (IDO), which could in turn cause immune suppression in the tumor microenvironment [54-58]. Indoleamine 2,3 dioxygenase 1 (IDO1) is an example of an IFN-stimulated gene (ISG) responsive to IFNs via IFN-response elements found in the mammalian IDO1 gene promoters. IDO is a tryptophan-catabolizing enzyme, which promotes the activation of $\mathrm{CD}^{+}$regulatory $\mathrm{T}$ cells mainly of the Foxp3-lineage and the subsequent suppression of effector and helper $\mathrm{T}$ cell functions [56]. In dendritic cells, IDO enhances immune tolerance by induction of transforming growth factor beta (TGF $\beta$ ) [55,57,59]. In a Lewis lung carcinoma mice model, Lemos et al. showed that knockout of STING caused enhanced killing of cancer cells due to increased $\mathrm{CD}^{+} \mathrm{T}$ cell activity, reduced myeloid suppressor cell infiltration, and high levels of IL10 production in the tumor microenvironment [55]. However, the induction of IDO did not produce the same effect in STING-deficient EL4 thymoma, B16 melanoma, and in neo-antigen-expressing lung carcinoma [55]. The immune-suppressive effect of IDO that leads to tumorigenesis is promoted in tumors with low antigenicity [55]. Hence, when tumor antigenicity is low, STING activation induces immune-regulatory responses via IDO predominantly, whereas, in tumors with high antigenicity, immune-stimulatory responses are enhanced [55]. Similarly, and perhaps, more importantly, adenosine produced by the adenosinergic pathway exhibits significant immunosuppressive effects in the tumor microenvironment and contributes to tumor progression [60,61]. ATP is rapidly dephosphorylated in a stepwise manner in the extracellular milieu by the ecto-nucleotidases, CD39 and CD73 [53]. Typically, CD39 converts ATP to ADP and ADP to AMP, while CD73 dephosphorylates AMP to adenosine (Figure 7) [60,62]. Additionally, in the usually hypoxic tumor microenvironment, hypoxia induces further CD39- and CD73-mediated adenosine production [63,64]. To add to this, hypoxia also inhibits breakdown of adenosine and potentiates adenosine release by downregulating adenosine kinase $[61,65]$. The increased production of adenosine and the inhibition of its breakdown ultimately leads to much higher levels of adenosine in tumors when compared to normal tissues [66]. The excess adenosine produced by these mechanisms essentially turns off both the innate and adaptive immune responses via G-protein-coupled $\mathrm{A}_{2 \mathrm{~A}}$ and $\mathrm{A}_{2 \mathrm{~B}}$ adenosine receptors that stimulate cyclic $\mathrm{AMP}$, consequently leading to decreased production of proinflammatory cytokines and increased synthesis of anti-inflammatory cytokines [44,65]. In cervical cancer-derived mesenchymal stromal cells (MSC), de Lourdes Mora-Garcia et al. demonstrated that cytotoxic T lymphocyte effector activity, including proliferation and production of IFN- $\gamma+$, were inhibited by adenosine in a dose-dependent manner [65]. Other studies by Garcia-Rocha et al. also reported that MSC derived from cervical cancer tumors induced the expression and secretion of anti-inflammatory cytokines, such as TGF- $\beta 1$ and IL- 10 , in cervical cancer cells, thereby protecting the cells from $\mathrm{T}$ cell cytotoxicity [67]. The hydrolysis of cGAMP by ENPP1 leads to the production of AMP, which eventually contributes to a more profound immunosuppression via the subsequent dephosphorylation of AMP to adenosine by CD73 [47]. The role of ENPP1 in cancer is exemplified by the observations of enhanced tumor metastasis to the bone 
from breast cancer, for example, by over-expression of ENPP1 [41]. The significance of ENPP1 and CD73-mediated production of adenosine is further demonstrated by several reports of resistance to carcinogenesis or metastasis by mice deficient in either CD73 or ENPP1 [41,63,68,69].

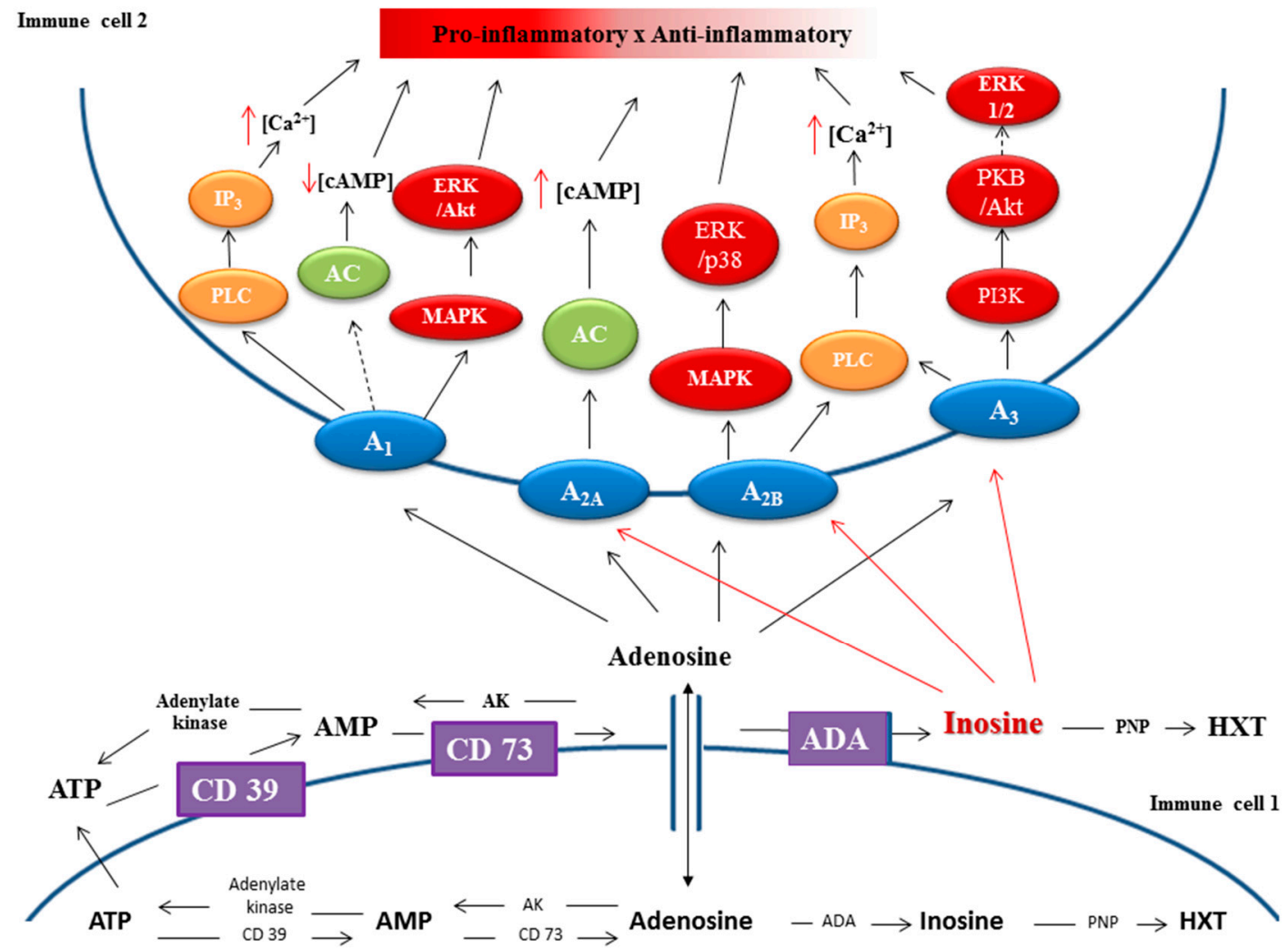

Figure 7. Scheme of the purinergic system in inflammation. Intracellular adenosine is produced from AMP or S-adenosylhomocysteine, which is then exported to the extracellular environment by nucleoside transporters, to stimulate several adenosine receptor-mediated signaling pathways. Extracellular adenosine acts as the signaling molecule that binds and stimulates the cell surface adenosine receptors $\left(\mathrm{A}_{1}, \mathrm{~A}_{2 \mathrm{~A}}, \mathrm{~A}_{2 \mathrm{~B}}\right.$, and $\left.\mathrm{A}_{3}\right)$ and triggers both pro-inflammatory and anti-inflammatory responses. $A_{1}$, adenosine $A 1$ receptor; $A_{2 A}$, adenosine $A 2 A$ receptor; $A_{2 B}$, adenosine $A 2 B$ receptor; $\mathrm{A}_{3}$, adenosine $\mathrm{A} 3$ receptor; $\mathrm{AC}$, adenylate cyclase; $\mathrm{AMP}$, cyclic adenosine monophosphate; ERK1/2, extracellular signal-regulated kinases 1 and 2; IP3, inositol triphosphate; MAPK, mitogen-activated protein kinase; PKB, protein kinase B; PLC, phospholipase C; PI3K, Phosphatidylinositide 3-kinase; ATP, adenosine triphosphate; AMP, adenosine monophosphate; HXT, hypoxanthine; AK, adenosine kinase; ADA, adenosine deaminase; PNP, purine nucleoside phosphorylase; ENTs, equilibrate nucleoside transporters; CD39, ectonucleoside triphosphate diphosphohydrolase; Inhibition $\rightarrow$; Activation - $\rightarrow$ [70]. Reproduced from Reference [70] with permission from Intech Open, Copyright 2014.

\section{Inhibitors of ENPP1}

\subsection{Nucleotide-Based Inhibitors of ENPP1}

The therapeutic potential of ENPP1 inhibitors has increased with the discovery of ENPP1's role in modulating the cGAS-STING pathway. In the past years, a few nucleotide-based ENPP1 inhibitors have been developed, which are mostly substrate analogs (Figure 8), such as adenine nucleotide derivatives [71-75]. These adenine nucleotide analog inhibitors of ENPP1 generally exhibit a competitive type of inhibition as their structures are similar to natural ENPP1 substrates [42]. Additionally, the inhibition properties of these nucleotide analogues appear to be similar. Using human soluble ENPP1 and ATP as substrates, $\mathrm{K}_{\mathrm{i}}$ for compounds $\alpha, \beta$-metADP, $\alpha, \beta$-metATP, 2-MeSADP, and 2-MeSATP, bzATP ranged from 13 to $32 \mu \mathrm{M}$, and was considered to be moderately potent $[42,71,72]$. 
Other nucleotide-based inhibitors have also been reported, such as $\gamma$-S- $\alpha, \beta$-metATP derivatives, ARL 67156, $\alpha$-borano- $\beta, \gamma$-metATP derivatives, and diadenosine boranophosphate derivatives. These other nucleotide inhibitors used p-Nph-5'-TMP or p-Nph-5'-AMP as substrates to achieve colorimetric detection of activity [73-75].<smiles>[X]CC1OC(n2cnc3c(N)ncnc32)[C@H](O)[C@@H]1O</smiles><smiles>[Y]OP(=O)(O)P(=O)(O)O</smiles><smiles>[Y]COP(=O)(O)P(=O)(O)OP(=O)(O)O</smiles><smiles>[Y]COP(=O)(O)P(=O)(O)OP(=O)(O)S</smiles><smiles>[Y]COP([B])(=O)OP(=O)(O)CP(=O)(O)O</smiles><smiles>[Y]C[C@H]1O[C@@H](n2cnc3c(N)nc(SC)nc32)[C@H](O)[C@@H]1O</smiles><smiles>[Y]=COP(=O)(O)OP(=O)(O)O</smiles>

2-MeSADP<smiles>[Y]=COP(=O)(O)OP(=O)(O)OP(=O)(O)O</smiles>

2-MeSATP

\section{$\alpha, \beta$-metATP}

\section{$\gamma$-S- $\alpha, \beta$-metATP derivative}

\section{$\alpha$-borano- $\beta, \gamma$-metATP derivative}<smiles>Nc1ncnc2c1ncn2[C@@H]1O[C@H](COP(=O)(O)OP(=O)(O)P(=O)(O)O)[C@@H](OC(=O)c2ccc(C(=O)c3ccccc3)cc2)[C@H]1O</smiles><smiles>CCN(CC)c1ncnc2c1ncn2C1OC(COP(=O)(O)P(=O)(O)C(Br)(Br)P(=O)(O)O)[C@@H](O)[C@H]1O</smiles><smiles>Nc1ncnc2c1ncn2C1O[C@H](COP(=O)(O)P(=O)(O)P(=O)(O)P(=O)(O)OP(=O)(O)P(=O)(O)OC[C@H]2O[C@@H](n3cnc4c(N)cccc43)CC2O)[C@@H](O)[C@H]1O</smiles>

\section{Diadenosine boranophosphate derivative}

Figure 8. Structures of nucleotide-based ENPP1 inhibitors.

However, the high acidity precludes oral bioavailability and limits the applicability of nucleotide-based inhibitors. Furthermore, the NPP1 selectivity of these inhibitors against other ectonucleotidases is not well understood. Since the structure of nucleotide-based inhibitors is similar to the structure of natural substrates, the possibility of off-target biological effects, such as P2 purinergic receptor activation, could also be enhanced. Consequently, nucleotide-based inhibitors may not be ideal lead candidates for the development of translatable ENPP1 inhibitors. 


\subsection{Non-Nucleotide-Based Inhibitors of ENPP1}

Many of the reported nucleotide-based inhibitors become negatively charged at physiological $\mathrm{pH}$ and have very poor oral bioavailability [76]. Nucleotide-based inhibitors also have very challenging synthesis and purification steps [76]. Non-nucleotide ENPP1 inhibitors have also been reported (Table 1). For example, polyoxometalates [TiW11CoO40] ${ }^{8-}$ were found to be one of the most potent ENPP1 inhibitors, with a $\mathrm{K}_{\mathrm{i}}$ of $1.46 \mathrm{nM}(0.00146 \mu \mathrm{M})$, when compared to other non-nucleotide human soluble enzyme inhibitors, such as reactive blue 2 (RB2), quinazoline derivative, and suramin, with a $K_{i}$ of $0.141,0.215$, and $0.780 \mu \mathrm{M}$, respectively [42]. Among the human membrane-bound enzyme inhibitors with ATP as a substrate, suramin had a superior $K_{i}$ of $0.26 \mu \mathrm{M}$ relative to RB2, with a $K_{i}$ of $0.52 \mu \mathrm{M}$. In contrast to nucleotide-based inhibitors, which exhibit competitive inhibition, suramin showed uncompetitive inhibition against the human soluble enzyme [42]. However, heparin, one of the first ENPP1 inhibitors, described about 2 decades ago, was reported to have a relatively high $\mathrm{IC}_{50}$ of $100 \mu \mathrm{M}$ [77]. Several other non-nucleotide-based inhibitors have been reported, where other substrates, such as ATP with a radioactive phosphorus atom at $\gamma$-position of the triphosphate $\left(\left[\gamma^{-32} \mathrm{P}\right] \mathrm{ATP}\right)$, etheno-diadenosine diphosphate, bis( $p$-nitrophenyl) phosphate, $p$-nitrophenyl phenyl phosphate, $p$-Nph-5'-TMP, or $p$-Nph-5'-AMP were used (Table 1) [42]. The $\mathrm{K}_{\mathrm{i}}$ values in these reports varied widely and ranged from 0.0593 to $1400 \mu \mathrm{M}$ (see Table 1) [71,76,78-81].

Most recently, in 2019, two new sulfamate derivatives were reported by Semreen et al. and El-Gamal et al., with an $\mathrm{IC}_{50}$ of 0.387 and $0.29 \mu \mathrm{M}$, respectively [82,83]. The sulfamate and sulfonate derivate described by El-Gamal was synthesized from a backbone of raloxifene hydrochloride [83]. Raloxifene is an FDA-approved selective estrogen receptor modulator used in the prevention and treatment of postmenopausal osteoporosis, and is known to reduce the risk of breast cancer [84]. Earlier in 2018, Forcellini et al. reported several novel quinazoline-4-piperidine sulfamide analogs as inhibitors of ENPP1 [85]. Among these, meta-pyridine substituted compound 7c was the most potent compound, with a $K_{i}$ of $58 \mathrm{nM}(0.058 \mu \mathrm{M})$ [85]. More recently, Weston et al. reported a new ENPP1 inhibitor, SR-8314, which promotes STING activation [86]. The $\mathrm{K}_{\mathrm{i}}$ value of SR-8314 against ENPP1 activity was reported as $0.079 \mu \mathrm{M}$. It was also shown that SR-8314 has anti-tumor activity with more $\mathrm{CD}^{+}$, $\mathrm{CD}^{+}$, and $\mathrm{CD}^{+} \mathrm{T}$ cells found in SR-8314 treatments compared to controls [86]. Baird et al. developed another selective ENPP1 inhibitor, MV-626, which prevents the hydrolysis of cGAMP, and increases STING activation [87]. Therapeutic doses of MV-626 did not show toxicity in mice [87]. In combination with radiation therapy, MV-626 increased overall survival, and the majority of test animals had durable tumor cures [87]. Currently, the ideal doses, intensities, and durations of such therapies has not been established. Generally, hyperactivation of host immune responses and ectopic calcifications by ENPP1 inhibition might be a concern, as discussed in a previous review [36]. However, ENPP1 knockout mice have remained viable, lending credence to the potential use of ENPP1 inhibitors without debilitating adverse outcomes. The addition of these new, more potent inhibitors into the growing array of ENPP1 inhibitors, is a reflection of the therapeutic usefulness of ENPP1 inhibition in immunotherapy. 
Table 1. Non-nucleotide-based inhibitors $\ddagger$.

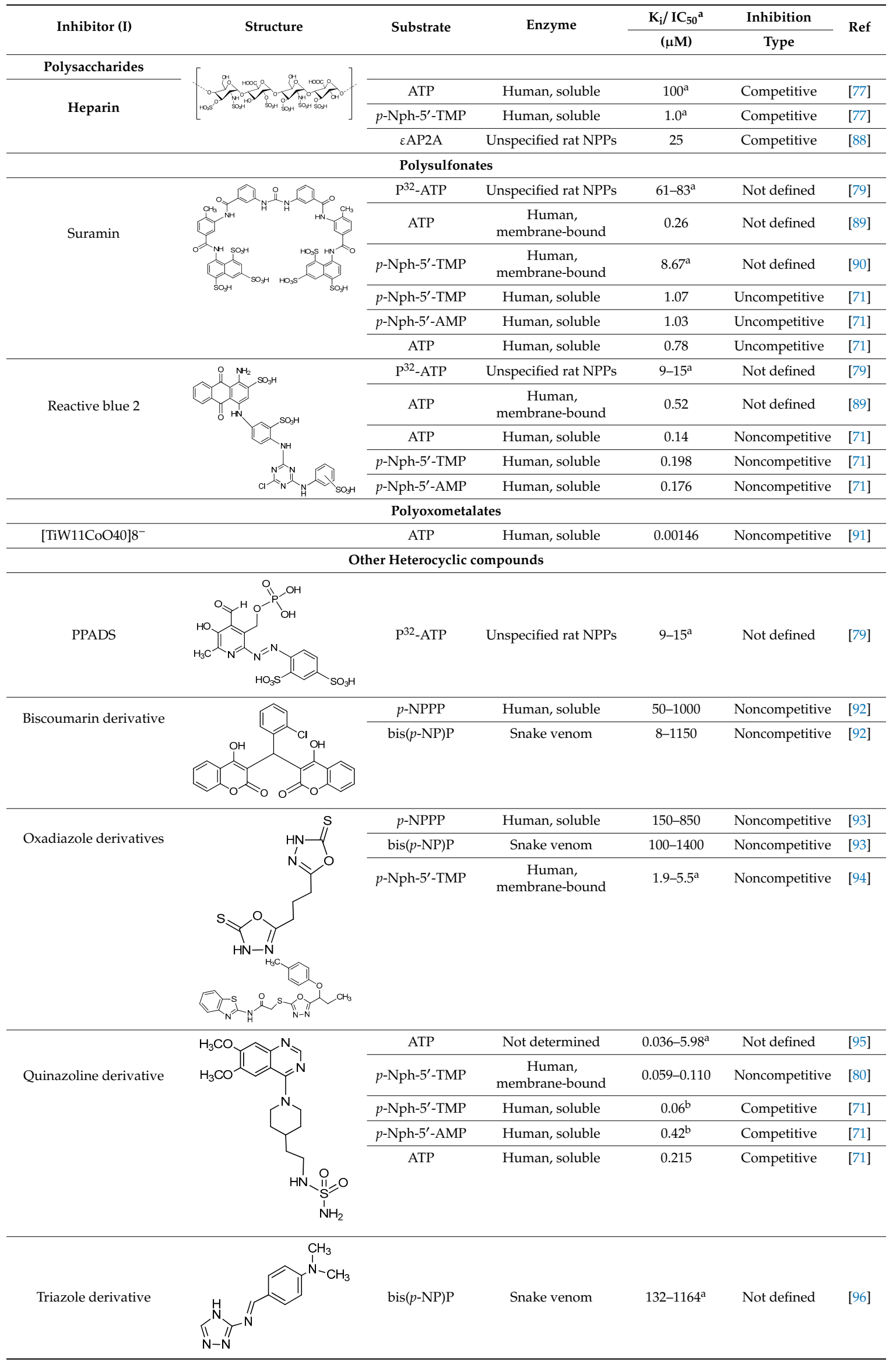


Table 1. Cont.

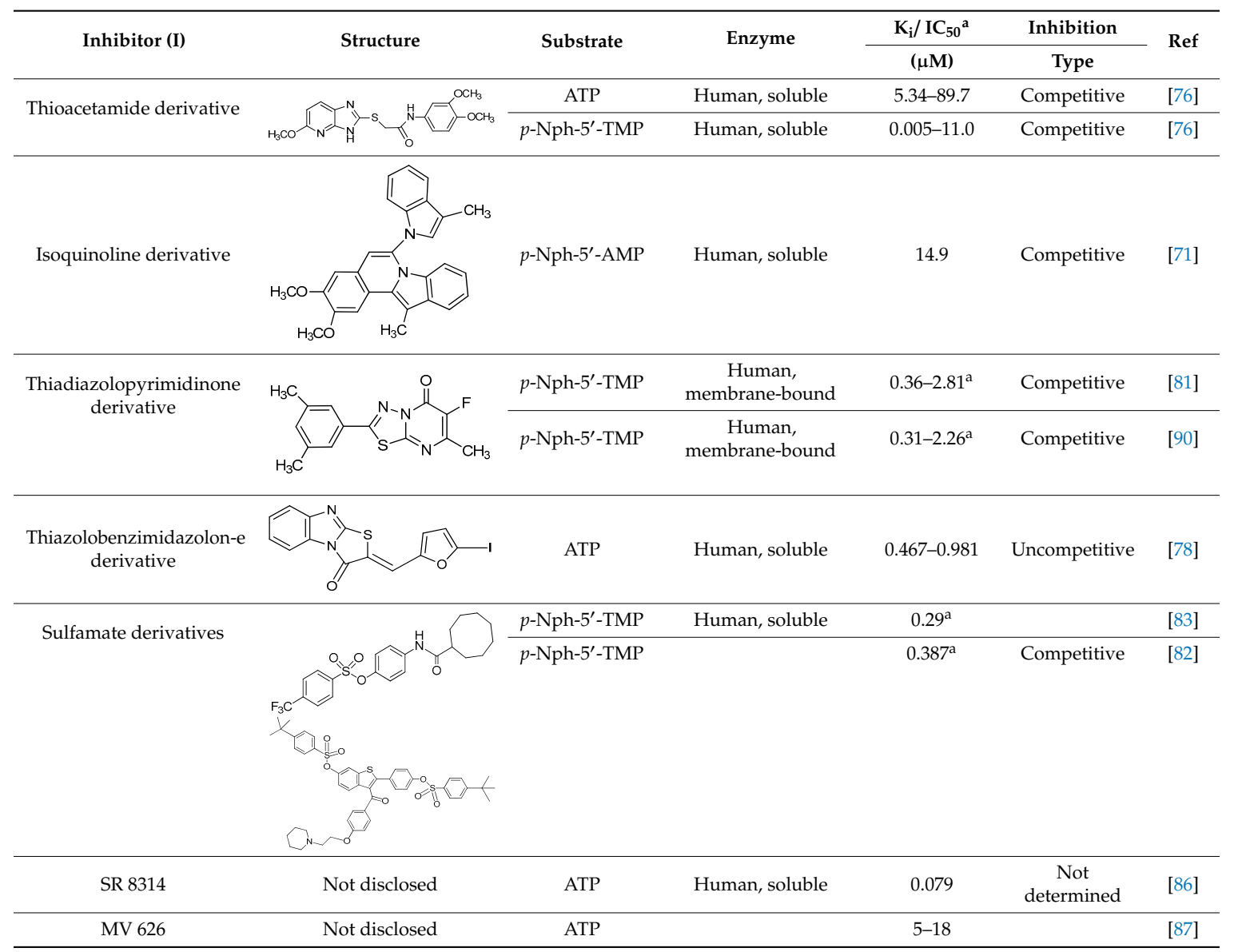

$\ddagger$ Adapted from Lee et al. 2017 [42] (updated with more recent inhibitors) with permission from the Royal Society of

Chemistry, Copyright 2017; ${ }^{\mathrm{a}}$ IC50 values, ${ }^{\mathrm{b}}$ Value determined with the most potent derivative of quinazolines.

\section{Conclusions}

In this review, we have discussed the mechanism and hydrolysis of the relatively new ENPP1 substrate, cGAMP, and that of ATP. We have also highlighted the typical and recently reported ENPP1 inhibitors, based on their classification as either nucleotide-based or non-nucleotide-based inhibitors. Since STING activation is a promising therapeutic strategy to cure cancer, more and more compounds that activate the STING pathway have been reported. ENPP1, as a highly potent cGAMP-degradation enzyme, makes the application of ENPP1 inhibitors for anti-tumor therapy a very topical issue. For virally-infected hosts, small molecule inhibitors of ENPP1 would also need to inhibit viral poxins for maximum efficacy.

Author Contributions: Conceptualization, H.O.S; literature search and methodology, H.O.S., K.I.O. and M.W; writing—original draft preparation, H.O.S, K.I.O. and M.W; writing—review and editing, H.O.S, K.I.O. and M.W.; supervision, H.O.S.; funding acquisition, H.O.S.

Funding: This research was funded by Purdue University.

Conflicts of Interest: The authors declare no conflict of interest.

\section{References}

1. Evans:, W.H.; Hood, D.O.; Gurd, J.W. Purification and properties of a mouse liver plasma-membrane glycoprotein hydrolysing nucleotide pyrophosphate and phosphodiester bonds. Biochem. J. 1973, 135, 819-826. [CrossRef] [PubMed] 
2. Takahashi, T.; Old, L.J.; Boyse, E.A. Surface alloantigens of plasma cells. J. Exp. Med. 1970, 131, $1325-1341$. [CrossRef] [PubMed]

3. Huang, R.; Rosenbach, M.; Vaughn, R.; Provvedini, D.; Rebbe, N.; Hickman, S.; Goding, J.; Terkeltaub, R. Expression of the murine plasma cell nucleotide pyrophosphohydrolase PC-1 is shared by human liver, bone, and cartilage cells. Regulation of PC-1 expression in osteosarcoma cells by transforming growth factor-beta. J. Clin. Invest. 1994, 94, 560-567. [CrossRef] [PubMed]

4. Burnstock, G. Purinergic signalling. Br. J. Pharmacol. 2006, 147 (Suppl. 1), S172-S181. [CrossRef]

5. Drury, A.N.; Szent-Györgyi, A. The physiological activity of adenine compounds with especial reference to their action upon the mammalian heart. J. Physiol. 1929, 68, 213-237. [CrossRef] [PubMed]

6. Idzko, M.; Ferrari, D.; Riegel, A.K.; Eltzschig, H.K. Extracellular nucleotide and nucleoside signaling in vascular and blood disease. Blood 2014, 124, 1029-1037. [CrossRef]

7. Roberts, F.; Zhu, D.; Farquharson, C.; Macrae, V.E. ENPP1 in the Regulation of Mineralization and Beyond. Trends Biochem. Sci. 2019, 44, 616-628. [CrossRef]

8. Stefan, C.; Jansen, S.; Bollen, M. NPP-type ectophosphodiesterases: Unity in diversity. Trends Biochem. Sci. 2005, 30, 542-550. [CrossRef]

9. Cimpean, A.; Stefan, C.; Gijsbers, R.; Stalmans, W.; Bollen, M. Substrate-specifying determinants of the nucleotide pyrophosphatases/phosphodiesterases NPP1 and NPP2. Biochem. J. 2004, 381, 71-77. [CrossRef]

10. Lorenz-Depiereux, B.; Schnabel, D.; Tiosano, D.; Häusler, G.; Strom, T.M. Loss-of-function ENPP1 mutations cause both generalized arterial calcification of infancy and autosomal-recessive hypophosphatemic rickets. Am. J. Hum. Genet. 2010, 86, 267-272. [CrossRef]

11. Eytan, O.; Morice-Picard, F.; Sarig, O.; Ezzedine, K.; Isakov, O.; Li, Q.; Ishida-Yamamoto, A.; Shomron, N.; Goldsmith, T.; Fuchs-Telem, D.; et al. Cole Disease Results from Mutations in ENPP1. Am. J. Hum. Genet. 2013, 93, 752-757. [CrossRef] [PubMed]

12. Thumbigere-Math, V.; Alqadi, A.; Chalmers, N.I.; Chavez, M.B.; Chu, E.Y.; Collins, M.T.; Ferreira, C.R.; FitzGerald, K.; Gafni, R.I.; Gahl, W.A.; et al. Hypercementosis Associated with ENPP1 Mutations and GACI. J. Dent. Res. 2018, 97, 432-441. [CrossRef] [PubMed]

13. Li, Q.; van de Wetering, K.; Uitto, J. Pseudoxanthoma Elasticum as a Paradigm of Heritable Ectopic Mineralization Disorders: Pathomechanisms and Treatment Development. Am. J. Pathol. 2019, 189, 216-225. [CrossRef] [PubMed]

14. Van Gils, M.; Nollet, L.; Verly, E.; Deianova, N.; Vanakker, O.M. Cellular signaling in pseudoxanthoma elasticum: An update. Cell. Signal. 2019, 55, 119-129. [CrossRef] [PubMed]

15. Devriese, M.; Legrand, A.; Courtois, M.C.; Jeunemaitre, X.; Albuisson, J. Pseudoxanthoma elasticum with prominent arterial calcifications evoking CD73 deficiency. Vasc. Med. 2019, 24, 461-464. [CrossRef] [PubMed]

16. Staretz-Chacham, O.; Shukrun, R.; Barel, O.; Pode-Shakked, B.; Pleniceanu, O.; Anikster, Y.; Shalva, N.; Ferreira, C.R.; Ben-Haim Kadosh, A.; Richardson, J.; et al. Novel homozygous ENPP1 mutation causes generalized arterial calcifications of infancy, thrombocytopenia, and cardiovascular and central nervous system syndrome. Am. J. Med. Genet. 2019, 179, 2112-2118. [CrossRef]

17. Quarles, L.D. Skeletal secretion of FGF-23 regulates phosphate and vitamin D metabolism. Nat. Rev. Endocrinol. 2012, 8, 276-286. [CrossRef]

18. Levy-Litan, V.; Hershkovitz, E.; Avizov, L.; Leventhal, N.; Bercovich, D.; Chalifa-Caspi, V.; Manor, E.; Buriakovsky, S.; Hadad, Y.; Goding, J.; et al. Autosomal-recessive hypophosphatemic rickets is associated with an inactivation mutation in the ENPP1 gene. Am. J. Hum. Genet. 2010, 86, 273-278. [CrossRef]

19. Quarles, L.D. Evidence for a bone-kidney axis regulating phosphate homeostasis. J. Clin. Invest. 2003, 112, 642-646. [CrossRef]

20. Chourabi, M.; Liew, M.S.; Lim, S.; H'mida-Ben Brahim, D.; Boussofara, L.; Dai, L.; Wong, P.M.; Foo, J.N.; Sriha, B.; Robinson, K.S.; et al. ENPP1 Mutation Causes Recessive Cole Disease by Altering Melanogenesis. J. Invest. Dermatol. 2018, 138, 291-300. [CrossRef]

21. Kato, K.; Nishimasu, H.; Okudaira, S.; Mihara, E.; Ishitani, R.; Takagi, J.; Aoki, J.; Nureki, O. Crystal structure of Enpp1, an extracellular glycoprotein involved in bone mineralization and insulin signaling. Proc. Natl. Acad. Sci. USA 2012, 109, 16876-16881. [CrossRef] [PubMed]

22. Goldfine, I.D.; Maddux, B.A.; Youngren, J.F.; Reaven, G.; Accili, D.; Trischitta, V.; Vigneri, R.; Frittitta, L. The role of membrane glycoprotein plasma cell antigen 1 /ectonucleotide pyrophosphatase phosphodiesterase 1 
in the pathogenesis of insulin resistance and related abnormalities. Endocr. Rev. 2008, 29, 62-75. [CrossRef] [PubMed]

23. Pan, W.; Ciociola, E.; Saraf, M.; Tumurbaatar, B.; Tuvdendorj, D.; Prasad, S.; Chandalia, M.; Abate, N. Metabolic consequences of ENPP1 overexpression in adipose tissue. Am. J. Physiol. Endocrinol. Metab. 2011, 301, E901-E911. [CrossRef] [PubMed]

24. Huesa, C.; Zhu, D.; Glover, J.D.; Ferron, M.; Karsenty, G.; Milne, E.M.; Millan, J.L.; Ahmed, S.F.; Farquharson, C.; Morton, N.M.; et al. Deficiency of the bone mineralization inhibitor NPP1 protects mice against obesity and diabetes. Dis. Model. Mech. 2014, 7, 1341-1350. [CrossRef]

25. Kato, K.; Nishimasu, H.; Oikawa, D.; Hirano, S.; Hirano, H.; Kasuya, G.; Ishitani, R.; Tokunaga, F.; Nureki, O. Structural insights into cGAMP degradation by Ecto-nucleotide pyrophosphatase phosphodiesterase 1. Nat. Commun. 2018, 9, 4424. [CrossRef] [PubMed]

26. Li, X.D.; Wu, J.; Gao, D.; Wang, H.; Sun, L.; Chen, Z.J. Pivotal roles of cGAS-cGAMP signaling in antiviral defense and immune adjuvant effects. Science 2013, 341, 1390-1394. [CrossRef] [PubMed]

27. Sun, L.; Wu, J.; Du, F.; Chen, X.; Chen, Z.J. Cyclic GMP-AMP synthase is a cytosolic DNA sensor that activates the type I interferon pathway. Science 2013, 339, 786-791. [CrossRef]

28. Wu, J.; Sun, L.; Chen, X.; Du, F.; Shi, H.; Chen, C.; Chen, Z.J. Cyclic GMP-AMP is an endogenous second messenger in innate immune signaling by cytosolic DNA. Science 2013, 339, 826-830. [CrossRef]

29. Haag, S.M.; Gulen, M.F.; Reymond, L.; Gibelin, A.; Abrami, L.; Decout, A.; Heymann, M.; van der Goot, F.G.; Turcatti, G.; Behrendt, R.; et al. Targeting STING with covalent small-molecule inhibitors. Nature 2018, 559, 269-273. [CrossRef]

30. Wang, J.; Lu, S.F.; Wan, B.; Ming, S.L.; Li, G.L.; Su, B.Q.; Liu, J.Y.; Wei, Y.S.; Yang, G.Y.; Chu, B.B. Maintenance of cyclic GMP-AMP homeostasis by ENPP1 is involved in pseudorabies virus infection. Mol. Immunol. 2018, 95, 56-63. [CrossRef]

31. Dey, R.J.; Dey, B.; Zheng, Y.; Cheung, L.S.; Zhou, J.; Sayre, D.; Kumar, P.; Guo, H.; Lamichhane, G.; Sintim, H.O.; et al. Inhibition of innate immune cytosolic surveillance by an M. tuberculosis phosphodiesterase. Nat. Chem. Biol. 2017, 13, 210-217. [CrossRef] [PubMed]

32. Li, L.; Yin, Q.; Kuss, P.; Maliga, Z.; Millán, J.L.; Wu, H.; Mitchison, T.J. Hydrolysis of 2'3'-cGAMP by ENPP1 and design of nonhydrolyzable analogs. Nat. Chem. Biol. 2014, 10, 1043-1048. [CrossRef] [PubMed]

33. Eaglesham, J.B.; Pan, Y.; Kupper, T.S.; Kranzusch, P.J. Viral and metazoan poxins are cGAMP-specific nucleases that restrict cGAS-STING signalling. Nature 2019, 566, 259-263. [CrossRef] [PubMed]

34. Danino, O.; Svetitsky, S.; Kenigsberg, S.; Levin, A.; Journo, S.; Gold, A.; Drexler, M.; Snir, N.; Elkayam, O.; Fischer, B.; et al. Inhibition of nucleotide pyrophosphatase/phosphodiesterase 1: Implications for developing a calcium pyrophosphate deposition disease modifying drug. Rheumatology 2018, 57, 1472-1480. [CrossRef] [PubMed]

35. Nitschke, Y.; Hartmann, S.; Torsello, G.; Horstmann, R.; Seifarth, H.; Weissen-Plenz, G.; Rutsch, F. Expression of NPP1 is regulated during atheromatous plaque calcification. J. Cell. Mol. Med. 2011, 15, 220-231. [CrossRef] [PubMed]

36. Sharma, M.; Thode, T.; Weston, A.; Kaadige, M.R. Development of Enpp1 Inhibitors as a Strategy to Activate Stimulator of Interferon Genes (STING) in Cancers and Other Diseases. Int. J. Cell Sci. Mol. Biol. 2018, 5, 1-5.

37. Abbasi, S.; Shin, D.M.; Beaty, N.; Masiuk, M.; Chen, S.; Gonzalez-Garcia, I.; Zhao, M.; Goding, J.; Morse, H.C.; Wang, H. Characterization of monoclonal antibodies to the plasma cell alloantigen ENPP1. Hybridoma (Larchmt) 2011, 30, 11-17. [CrossRef]

38. Yoon, J.; Wang, H.; Kim, Y.C.; Yoshimoto, M.; Abbasi, S.; Morse Iii, H.C. Plasma cell alloantigen ENPP1 is expressed by a subset of human B cells with potential regulatory functions. Immunol. Cell. Biol. 2016, 94, 719-728. [CrossRef]

39. Kaneda, M.M.; Messer, K.S.; Ralainirina, N.; Li, H.; Leem, C.J.; Gorjestani, S.; Woo, G.; Nguyen, A.V.; Figueiredo, C.C.; Foubert, P.; et al. PI3K $\gamma$ is a molecular switch that controls immune suppression. Nature 2016, 539, 437-442. [CrossRef]

40. Grobben, B.; De Deyn, P.P.; Slegers, H. Rat C6 glioma as experimental model system for the study of glioblastoma growth and invasion. Cell Tissue Res. 2002, 310, 257-270. [CrossRef]

41. Lau, W.M.; Doucet, M.; Stadel, R.; Huang, D.; Weber, K.L.; Kominsky, S.L. Enpp1: A potential facilitator of breast cancer bone metastasis. PLoS ONE 2013, 8, e66752. [CrossRef] [PubMed] 
42. Lee, S.-Y.; Müller, C.E. Nucleotide pyrophosphatase/phosphodiesterase 1 (NPP1) and its inhibitors. MedChem Comm 2017, 8, 823-840. [CrossRef] [PubMed]

43. Bischoff, E.; Tran-Thi, T.-A.; Decker, K.F.A. Nucleotide Pyrophosphatase of Rat Liver. Eur. J. Biochem. 1975, 51, 353-361. [CrossRef] [PubMed]

44. Antonioli, L.; Pacher, P.; Vizi, E.S.; Haskó, G. CD39 and CD73 in immunity and inflammation. Trends. Mol. Med. 2013, 19, 355-367. [CrossRef]

45. Johnson, K.; Goding, J.; Van Etten, D.; Sali, A.; Hu, S.-I.; Farley, D.; Krug, H.; Hessle, L.; Millán, J.L.; Terkeltaub, R. Linked Deficiencies in Extracellular PPi and Osteopontin Mediate Pathologic Calcification Associated With Defective PC-1 and ANK Expression. J. Bone Miner. Res. 2003, 18, 994-1004. [CrossRef]

46. Johnson, K.; Moffa, A.; Chen, Y.; Pritzker, K.; Goding, J.; Terkeltaub, R. Matrix Vesicle Plasma Cell Membrane Glycoprotein-1 Regulates Mineralization by Murine Osteoblastic MC3T3 Cells. J. Bone Miner. Res. 1999, 14, 883-892. [CrossRef]

47. Horenstein, A.L.; Chillemi, A.; Zaccarello, G.; Bruzzone, S.; Quarona, V.; Zito, A.; Serra, S.; Malavasi, F. A CD38/CD203a/CD73 ectoenzymatic pathway independent of CD39 drives a novel adenosinergic loop in human T lymphocytes. OncoImmunology 2013, 2, e26246. [CrossRef]

48. Namasivayam, V.; Lee, S.-Y.; Müller, C.E. The promiscuous ectonucleotidase NPP1: Molecular insights into substrate binding and hydrolysis. Biochim. Biophys. Acta 2017, 1861, 603-614. [CrossRef]

49. Wielinga, P.R.; van der Heijden, I.; Reid, G.; Beijnen, J.H.; Wijnholds, J.; Borst, P. Characterization of the MRP4- and MRP5-mediated Transport of Cyclic Nucleotides from Intact Cells. J. Biol. Chem. 2003, 278, 17664-17671. [CrossRef]

50. Jedlitschky, G.; Burchell, B.; Keppler, D. The Multidrug Resistance Protein 5 Functions as an ATP-dependent Export Pump for Cyclic Nucleotides. J. Biol. Chem. 2000, 275, 30069-30074. [CrossRef]

51. Guo, Y.; Kotova, E.; Chen, Z.-S.; Lee, K.; Hopper-Borge, E.; Belinsky, M.G.; Kruh, G.D. MRP8, ATP-binding Cassette C11 (ABCC11), Is a Cyclic Nucleotide Efflux Pump and a Resistance Factor for Fluoropyrimidines 2', 3'-Dideoxycytidine and 9'-(2'-Phosphonylmethoxyethyl)adenine. J. Biol. Chem. 2003, 278, 29509-29514. [CrossRef] [PubMed]

52. Pham, H.T.; Nhiep, N.T.H.; Vu, T.N.M.; Huynh, T.N.; Zhu, Y.; Huynh, A.L.D.; Chakrabortti, A.; Marcellin, E.; Lo, R.; Howard, C.B.; et al. Enhanced uptake of potassium or glycine betaine or export of cyclic-di-AMP restores osmoresistance in a high cyclic-di-AMP Lactococcus lactis mutant. PLoS Genet. 2018, 14, e1007574. [CrossRef] [PubMed]

53. Conti, M. Phosphodiesterases and cyclic nucleotide signaling in endocrine cells. Mol. Endocrinol. 2000, 14, 1317-1327. [CrossRef] [PubMed]

54. Corrales, L.; McWhirter, S.M.; Dubensky, T.W.; Gajewski, T.F. The host STING pathway at the interface of cancer and immunity. J. Clin. Invest. 2016, 126, 2404-2411. [CrossRef] [PubMed]

55. Lemos, H.; Mohamed, E.; Huang, L.; Ou, R.; Pacholczyk, G.; Arbab, A.S.; Munn, D.; Mellor, A.L. STING Promotes the Growth of Tumors Characterized by Low Antigenicity via IDO Activation. Cancer Res. 2016, 76, 2076-2081. [CrossRef] [PubMed]

56. Lemos, H.; Huang, L.; McGaha, T.L.; Mellor, A.L. Cytosolic DNA sensing via the stimulator of interferon genes adaptor: Yin and Yang of immune responses to DNA. Eur. J. Immunol. 2014, 44, 2847-2853. [CrossRef]

57. Huang, L.; Li, L.; Lemos, H.; Chandler, P.R.; Pacholczyk, G.; Baban, B.; Barber, G.N.; Hayakawa, Y.; McGaha, T.L.; Ravishankar, B.; et al. Cutting edge: DNA sensing via the STING adaptor in myeloid dendritic cells induces potent tolerogenic responses. J. Immunol. 2013, 191, 3509-3513. [CrossRef]

58. Liu, M.; Wang, X.; Wang, L.; Ma, X.; Gong, Z.; Zhang, S.; Li, Y. Targeting the IDO1 pathway in cancer: From bench to bedside. J. Hematol. Oncol. 2018, 11, 100. [CrossRef]

59. Munn, D.H.; Sharma, M.D.; Lee, J.R.; Jhaver, K.G.; Johnson, T.S.; Keskin, D.B.; Marshall, B.; Chandler, P.; Antonia, S.J.; Burgess, R.; et al. Potential regulatory function of human dendritic cells expressing indoleamine 2,3-dioxygenase. Science 2002, 297, 1867-1870. [CrossRef]

60. Vijayan, D.; Young, A.; Teng, M.W.L.; Smyth, M.J. Targeting immunosuppressive adenosine in cancer. Nat. Rev. Cancer 2017, 17, 709-724. [CrossRef]

61. Vigano, S.; Alatzoglou, D.; Irving, M.; Ménétrier-Caux, C.; Caux, C.; Romero, P.; Coukos, G. Targeting Adenosine in Cancer Immunotherapy to Enhance T-Cell Function. Front. Immunol. 2019, 10, 925. [CrossRef] [PubMed] 
62. Zimmermann, H.; Zebisch, M.; Sträter, N. Cellular function and molecular structure of ecto-nucleotidases. Purinergic Signal. 2012, 8, 437-502. [CrossRef] [PubMed]

63. Allard, B.; Longhi, M.S.; Robson, S.C.; Stagg, J. The ectonucleotidases CD39 and CD73: Novel checkpoint inhibitor targets. Immunol. Rev. 2017, 276, 121-144. [CrossRef] [PubMed]

64. Rao, S.R.; Snaith, A.E.; Marino, D.; Cheng, X.; Lwin, S.T.; Orriss, I.R.; Hamdy, F.C.; Edwards, C.M. Tumour-derived alkaline phosphatase regulates tumour growth, epithelial plasticity and disease-free survival in metastatic prostate cancer. Br. J. Cancer 2017, 116, 227-236. [CrossRef]

65. de Lourdes Mora-García, M.; García-Rocha, R.; Morales-Ramírez, O.; Montesinos, J.J.; Weiss-Steider, B.; Hernández-Montes, J.; Ávila-Ibarra, L.R.; Don-López, C.A.; Velasco-Velázquez, M.A.; Gutiérrez-Serrano, V.; et al. Mesenchymal stromal cells derived from cervical cancer produce high amounts of adenosine to suppress cytotoxic T lymphocyte functions. J. Transl. Med. 2016, 14, 302. [CrossRef]

66. Montalbán Del Barrio, I.; Penski, C.; Schlahsa, L.; Stein, R.G.; Diessner, J.; Wöckel, A.; Dietl, J.; Lutz, M.B.; Mittelbronn, M.; Wischhusen, J.; et al. Adenosine-generating ovarian cancer cells attract myeloid cells which differentiate into adenosine-generating tumor associated macrophages-A self-amplifying, CD39and CD73-dependent mechanism for tumor immune escape. J. Immunother. Cancer 2016, 4, 49. [CrossRef]

67. García-Rocha, R.; Moreno-Lafont, M.; Mora-García, M.L.; Weiss-Steider, B.; Montesinos, J.J.; Piña-Sánchez, P.; Monroy-García, A. Mesenchymal stromal cells derived from cervical cancer tumors induce TGF- $\beta 1$ expression and IL-10 expression and secretion in the cervical cancer cells, resulting in protection from cytotoxic T cell activity. Cytokine 2015, 76, 382-390. [CrossRef]

68. Stagg, J.; Beavis, P.A.; Divisekera, U.; Liu, M.C.; Möller, A.; Darcy, P.K.; Smyth, M.J. CD73-deficient mice are resistant to carcinogenesis. Cancer Res. 2012, 72, 2190-2196. [CrossRef]

69. Stagg, J.; Divisekera, U.; Duret, H.; Sparwasser, T.; Teng, M.W.; Darcy, P.K.; Smyth, M.J. CD73-deficient mice have increased antitumor immunity and are resistant to experimental metastasis. Cancer Res. 2011, 71, 2892-2900. [CrossRef]

70. Lapa, F.D.; Júnior, S.J.; Cerutti, M.L.; Santos, A.R. Pharmacology and Therapeutics. In Pharmacology of Adenosine Receptors and Their Signaling Role in Immunity and Inflammation; Gowder, S.J.T., Ed.; IntechOpen: London, UK, 2014; pp. 86-130.

71. Lee, S.-Y.; Sarkar, S.; Bhattarai, S.; Namasivayam, V.; De Jonghe, S.; Stephan, H.; Herdewijn, P.; El-Tayeb, A.; Müller, C.E. Substrate-Dependence of Competitive Nucleotide Pyrophosphatase/Phosphodiesterase1 (NPP1) Inhibitors. Front. Pharmacol. 2017, 8. [CrossRef]

72. Lee, S.-Y.; Müller, C.E. Large-volume sample stacking with polarity switching for monitoring of nucleotide pyrophosphatase/phosphodiesterase 1 (NPP1) reactions by capillary electrophoresis. Electrophoresis 2014, 35, 855-863. [CrossRef] [PubMed]

73. Nadel, Y.; Lecka, J.; Gilad, Y.; Ben-David, G.; Förster, D.; Reiser, G.; Kenigsberg, S.; Camden, J.; Weisman, G.A.; Senderowitz, H.; et al. Highly Potent and Selective Ectonucleotide Pyrophosphatase/Phosphodiesterase I Inhibitors Based on an Adenosine $5^{\prime}-(\alpha$ or $\gamma)$-Thio- $(\alpha, \beta$ - or $\beta, \gamma)$-methylenetriphosphate Scaffold. J. Med. Chem. 2014, 57, 4677-4691. [CrossRef] [PubMed]

74. Lévesque, S.A.; Lavoie, É.G.; Lecka, J.; Bigonnesse, F.; Sévigny, J. Specificity of the ecto-ATPase inhibitor ARL 67156 on human and mouse ectonucleotidases. Br. J. Pharmacol. 2007, 152, 141-150. [CrossRef] [PubMed]

75. Lecka, J.; Ben-David, G.; Simhaev, L.; Eliahu, S.; Oscar, J.; Luyindula, P.; Pelletier, J.; Fischer, B.; Senderowitz, H.; Sévigny, J. Nonhydrolyzable ATP Analogues as Selective Inhibitors of Human NPP1: A Combined Computational/Experimental Study. J. Med. Chem. 2013, 56, 8308-8320. [CrossRef] [PubMed]

76. Chang, L.; Lee, S.Y.; Leonczak, P.; Rozenski, J.; De Jonghe, S.; Hanck, T.; Müller, C.E.; Herdewijn, P. Imidazopyridine- and purine-thioacetamide derivatives: Potent inhibitors of nucleotide pyrophosphatase/phosphodiesterase 1 (NPP1). J. Med. Chem. 2014, 57, 10080-10100. [CrossRef] [PubMed]

77. Hosoda, N.; Hoshino, S.I.; Kanda, Y.; Katada, T. Inhibition of phosphodiesterase/pyrophosphatase activity of PC-1 by its association with glycosaminoglycans. Eur. J. Biochem. 1999, 265, 763-770. [CrossRef]

78. Lee, S.Y.; Perotti, A.; De Jonghe, S.; Herdewijn, P.; Hanck, T.; Müller, C.E. Thiazolo[3,2-a]benzimidazol-3(2H)-one derivatives: Structure-activity relationships of selective nucleotide pyrophosphatase/phosphodiesterase1 (NPP1) inhibitors. Bioorg. Med. Chem. 2016, 24, 3157-3165. [CrossRef] 
79. Grobben, B.; Claes, P.; Roymans, D.; Esmans, E.L.; Van Onckelen, H.; Slegers, H. Ecto-nucleotide pyrophosphatase modulates the purinoceptor-mediated signal transduction and is inhibited by purinoceptor antagonists. Br. J. Pharmacol. 2000, 130, 139-145. [CrossRef]

80. Shayhidin, E.E.; Forcellini, E.; Boulanger, M.C.; Mahmut, A.; Dautrey, S.; Barbeau, X.; Lagüe, P.; Sévigny, J.; Paquin, J.F.; Mathieu, P. Quinazoline-4-piperidine sulfamides are specific inhibitors of human NPP1 and prevent pathological mineralization of valve interstitial cells. Br. J. Pharmacol. 2015, 172, 4189-4199. [CrossRef]

81. Ausekle, E.; Ejaz, S.A.; Khan, S.U.; Ehlers, P.; Villinger, A.; Lecka, J.; Sévigny, J.; Iqbal, J.; Langer, P. New one-pot synthesis of $\mathrm{N}$-fused isoquinoline derivatives by palladium-catalyzed $\mathrm{C}-\mathrm{H}$ arylation: Potent inhibitors of nucleotide pyrophosphatase-1 and -3. Org. Biomol. Chem. 2016, 14, 11402-11414. [CrossRef]

82. Semreen, M.H.; El-Gamal, M.I.; Ullah, S.; Jalil, S.; Zaib, S.; Anbar, H.S.; Lecka, J.; Sévigny, J.; Iqbal, J. Synthesis, biological evaluation, and molecular docking study of sulfonate derivatives as nucleotide pyrophosphatase/phosphodiesterase (NPP) inhibitors. Bioorg. Med. Chem. 2019, 27, 2741-2752. [CrossRef] [PubMed]

83. El-Gamal, M.I.; Ullah, S.; Zaraei, S.O.; Jalil, S.; Zaib, S.; Zaher, D.M.; Omar, H.A.; Anbar, H.S.; Pelletier, J.; Sévigny, J.; et al. Synthesis, biological evaluation, and docking studies of new raloxifene sulfonate or sulfamate derivatives as inhibitors of nucleotide pyrophosphatase/phosphodiesterase. Eur. J. Med. Chem. 2019, 181, 111560. [CrossRef] [PubMed]

84. Rey, J.R.; Cervino, E.V.; Rentero, M.L.; Crespo, E.C.; Alvaro, A.O.; Casillas, M. Raloxifene: Mechanism of action, effects on bone tissue, and applicability in clinical traumatology practice. Open Orthop. J. 2009, 3, 14-21. [CrossRef] [PubMed]

85. Forcellini, E.; Boutin, S.; Lefebvre, C.-A.; Shayhidin, E.E.; Boulanger, M.-C.; Rhéaume, G.; Barbeau, X.; Lagüe, P.; Mathieu, P.; Paquin, J.-F. Synthesis and biological evaluation of novel quinazoline-4-piperidinesulfamide derivatives as inhibitors of NPP1. Eur. J. Med. Chem. 2018, 147, 130-149. [CrossRef]

86. Weston, A.; Thode, T.; Munoz, R.; Daniel, S.; Soldi, R.; Kaadige, M.; Han, H.; Vankayalapti, H.; Sharma, S. Abstract 3077: Preclinical studies of SR-8314, a highly selective ENPP1 inhibitor and an activator of STING pathway. Cancer Res. 2019, 79, 3077. [CrossRef]

87. Baird, J.; Dietsch, G.; Florio, V.; Gallatin, M.; Knox, C.; Odingo, J.; Crittenden, M.; Gough, M.J. MV-626, a potent and selective inhibitor of ENPP1 enhances STING activation and augments T-cell mediated anti-tumor activity in vivo. In Proceedings of the 33rd Annual Meeting of the Society for Immunotherapy of Cancer, Walter E. Washington Convention Center, Washington, DC, USA, 7-11 November 2018; p. 410.

88. Asensio, A.C.; Rodríguez-Ferrer, C.R.; Castañeyra-Perdomo, A.; Oaknin, S.; Rotllán, P. Biochemical analysis of ecto-nucleotide pyrophosphatase phosphodiesterase activity in brain membranes indicates involvement of NPP1 isoenzyme in extracellular hydrolysis of diadenosine polyphosphates in central nervous system. Neurochem. Int. 2007, 50, 581-590. [CrossRef]

89. Iqbal, J.; Lévesque, S.A.; Sévigny, J.; Müller, C.E. A highly sensitive CE-UV method with dynamic coating of silica-fused capillaries for monitoring of nucleotide pyrophosphatase/phosphodiesterase reactions. Electrophoresis 2008, 29, 3685-3693. [CrossRef]

90. Jafari, B.; Yelibayeva, N.; Ospanov, M.; Ejaz, S.A.; Afzal, S.; Khan, S.U.; Abilov, Z.A.; Turmukhanova, M.Z.; Kalugin, S.N.; Safarov, S.; et al. Synthesis of 2-arylated thiadiazolopyrimidones by Suzuki-Miyaura cross-coupling: A new class of nucleotide pyrophosphatase (NPPs) inhibitors. RSC Adv. 2016, 6, 107556-107571. [CrossRef]

91. Lee, S.Y.; Fiene, A.; Li, W.; Hanck, T.; Brylev, K.A.; Fedorov, V.E.; Lecka, J.; Haider, A.; Pietzsch, H.J.; Zimmermann, H.; et al. Polyoxometalates-Potent and selective ecto-nucleotidase inhibitors. Biochem. Pharmacol. 2015, 93, 171-181. [CrossRef]

92. Choudhary, M.I.; Fatima, N.; Khan, K.M.; Jalil, S.; Iqbal, S.; Atta-Ur-Rahman. New biscoumarin derivatives-cytotoxicity and enzyme inhibitory activities. Bioorg. Med. Chem. 2006, 14, 8066-8072. [CrossRef]

93. Khan, K.M.; Fatima, N.; Rasheed, M.; Jalil, S.; Ambreen, N.; Perveen, S.; Choudhary, M.I. 1,3,4-Oxadiazole-2(3H)-thione and its analogues: A new class of non-competitive nucleotide pyrophosphatases/phosphodiesterases 1 inhibitors. Bioorg. Med. Chem. 2009, 17, 7816-7822. [CrossRef] [PubMed] 
94. Raza, R.; Akhtar, T.; Hameed, S.; Lecka, J.; Iqbal, J.; Sévigny, J. Identification of Potent and Selective Human Ecto-Nucleotide Pyrophosphatase/Phosphodiesterase-3 (hNPP3) Inhibitors. Open Enzym. Inhib. J. 2011, 4, 17-22.

95. Patel, S.D.; Habeski, W.M.; Cheng, A.C.; de la Cruz, E.; Loh, C.; Kablaoui, N.M. Quinazolin-4-piperidin-4-methyl sulfamide PC-1 inhibitors: Alleviating hERG interactions through structure based design. Bioorg. Med. Chem. Lett. 2009, 19, 3339-3343. [CrossRef] [PubMed]

96. Khan, K.M.; Siddiqui, S.; Saleem, M.; Taha, M.; Saad, S.M.; Perveen, S.; Choudhary, M.I. Synthesis of triazole Schiff bases: Novel inhibitors of nucleotide pyrophosphatase/phosphodiesterase-1. Bioorg. Med. Chem. 2014, 22, 6509-6514. [CrossRef]

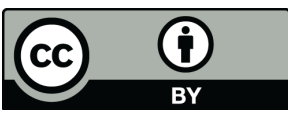

(C) 2019 by the authors. Licensee MDPI, Basel, Switzerland. This article is an open access article distributed under the terms and conditions of the Creative Commons Attribution (CC BY) license (http://creativecommons.org/licenses/by/4.0/). 